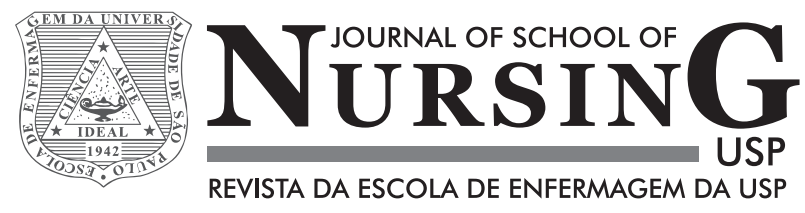

\title{
Usage of Calendula officinalis in the prevention and treatment of radiodermatitis: a randomized double-blind controlled clinical trial*
}

\author{
Uso da Calendula officinalis na prevenção e tratamento de \\ radiodermatite: ensaio clínico randomizado duplo cego \\ Uso de la Calendula officinalis en la prevención y tratamiento de \\ radiodermatitis: ensayo clínico randomizado doble ciego
}

Franciane Schneider ${ }^{1}$, Mitzy Tannia Reichembach Danski², Stela Adami Vayego ${ }^{3}$

\footnotetext{
* Extracted from the master's thesis "Uso da Calendula officinalis na prevenção e tratamento de radiodermite em cabeça e pescoço: ensaio clínico randomizado duplo cego", Graduate Program in Nursing, Universidade Federal do Paraná, 2012.

${ }^{1} \mathrm{MSc}$, Universidade Federal do Paraná, Curitiba, PR, Brazil.

${ }^{2}$ Associate Professor, Nursing Department, Universidade Federal do Paraná, Curitiba, PR, Brazil.

${ }^{3}$ Associate Professor, Statistics Department, Universidade Federal do Paraná, Curitiba, PR, Brazil.
}

\begin{abstract}
Objective: To evaluate the efficacy of Calendula officinalis in relation to Essential Fatty Acids for the prevention and treatment of radiodermatitis. Method: This is a randomized double-blind controlled clinical trial with 51 patients with head and neck cancer in radiotherapy treatment divided into two groups: control (27) and experimental (24). Results: There is statistically significant evidence ( $p$-value $=0.0120)$ that the proportion of radiodermatitis grade 2 in Essential Fatty Acids group is higher than Calendula group. Through the Kaplan-Meier survival curve we observed that Essential Fatty Acids group has always remained below the Calendula group survival curve, due to the lower risk of developing radiodermatitis grade 1 , which makes the usage of Calendula more effective, with statistical significance $(\mathrm{p}$-value $=0.00402)$. Conclusion: Calendula showed better therapeutic response than the Essential Fatty Acids in the prevention and treatment of radiodermatitis.

Brazilian Registry of Clinical Trials: RBR-237v4b.
\end{abstract}

\section{DESCRIPTORS}

Calendula; Radiodermatitis; Clinical Nursing Research; Oncology Nursing; Clinical Trial.
Correspondence Addressed to:

Franciane Schneider

Universidade Federal do Paraná, Setor de Ciências da Saúde Enfermagem.

Av. Lothário Meissner, 632, Sala 12, $3^{\circ}$ andar Bairro Jardim Botânico

CEP 80210-170 - Curitiba, PR, Brazil

franciane_06@yahoo.com.br
Received: 07/18/2014

Approved: 11/21/2014 


\section{INTRODUCTION}

One of the most common adverse effects of radiotherapy is the radiodermatitis, skin reactions limited to the treatment field or to its endpoint. Radiodermatitis is defined as a group of skin lesions caused by excessive exposure to ionizing radiation, which may lead to dehydration of the skin, sometimes causing serious complications (ulceration, local infection $)^{(1-3)}$.

In patients with head and neck cancer, due to the location of the treatment field, radiodermatitis is more commonly developed because the skin site is the more sensitive and has more skinfolds, causing constant friction and moisture. These are patients who also have an unfavorable nutritional status, having little fat tissue in the irradiated region, resulting in greater skin fragility. Often, these patients also perform concomitant treatment to chemotherapy, which enhances this adverse effect ${ }^{(3-4)}$.

The decision on what to use to minimize the development of radiodermatitis in patients will depend on the degree of skin toxicity, nurse's evaluation and applicability of each product. There are some recommendations for interventions and/or products for the prevention and treatment of radiodermatitis, such as: compresses with chamomile tea or filtered water, lotion based on essential fatty acid (EFA) or unsaturated fatty acid (UFA), Aloe Vera, extrafine hydrocolloid plate, among others ${ }^{(5)}$.

One of the recommended products, in both the prevention and treatment of radiodermatitis grades 1 to 4 , is the essential fatty acid (EFA) $)^{(5-6)}$, which is the standard product for the nursing staff of the institution of this research for the prevention and treatment of these skin lesions.

Some studies indicate other therapeutic modalities, one of them is the usage of Calendula officinalis (phytotherapy) due to its clinical actions ${ }^{(1,5)}$. This is a medicinal plant that has the following properties: antiseptic, bactericidal, fungistatic, virucidal, antiulcerative, antiphlogistic, antiallergic, restorative properties for skins that are difficult to heal, antiedema, soothing and refreshing for sensitive $\operatorname{skin}^{(5,7)}$. It is recommended for use in the prevention of dermatitis and radiodermatitis ${ }^{(8)}$. The use of Calendula topically for antiinflammatory and healing therapeutic actions is suggested by the Brazilian National Health Surveillance Agency (ANVISA) ${ }^{(9)}$.

Thus, the objective was to evaluate the efficacy of Calendula officinalis comparing to essential fatty acids (EFA) in the prevention and treatment of radiodermatitis in patients with head and neck cancer, based on toxicity criteria of the Radiation Therapy Oncology Group (RTOG).

The choice of these two products (EFA and Calendula) is justified because both are allowed and indicated for this type of skin lesion ${ }^{(1,5-6,8-9)}$. However, there are incipient studies based on scientific evidence indicating nursing care and/ or products to be used in the prevention and/or treatment of radiodermatitis, uncomfortable and painful adverse effects to the patient ${ }^{(2)}$. Thus, it is emphasized that the relevance of this research lies in the scarcity of randomized controlled trials in the nursing area of cancer, which are essential for implementing a secure, efficient and quality care to the patient.

\section{METHODS}

The research was approved by the Research Ethics Committee (REC) of the hospital under protocol CAAE 0043.0.088.000-11. All participants signed the Consent Form $(\mathrm{CF})$ prior to their inclusion in the study.

This is a randomized double blind controlled clinical trial conducted in Radiotherapy department of a philanthropic hospital specialized in oncology in the city of Curitiba located in the state of Parana. The hospital attends adult and pediatric patients with cancer. Data were collected from October 2011 to May 2012. The recruitment and selection occurred through a computerized system of the hospital.

The study included patients of both sexes, aged over 18 years, diagnosed with head and neck cancer, from the first day of radiotherapy session (new cases) and who agreed to participate in the research. We excluded those who had tumor wounds in the head and neck, previous history of radiotherapy in the same treatment field, or previous reports of allergic reaction in the use of one of the research products (EFA or Calendula).

We excluded participants who used any other product on the skin at the treatment site at any time of the study and had an allergic reaction to the products or had deficits to adhere to the research intervention and follow-up of the study recommendations. The compounding pharmacy was responsible for the manufacture of both products, absolute secrecy of records was maintained, as well as the identification number and the product contained in the bottles. The bottles were identical, as well as the presentation of both products (oil). The product had the following components: EFA - sunflower oil, $1 \%$ vitamin A, $0.2 \%$ vitamin $\mathrm{E}$ and $5 \%$ caprylic acid and Calendula - 4\% Calendula oil, $1 \%$ vitamin $\mathrm{A}$ and liquid vaseline.

The filling of bottles in pharmacy was random, yet at the same rate for both groups, and the researchers did not have access to this information. The bottles were sent to the researchers identified only by numbers, so that the study could be characterized as double-blind. Only after the data analysis the researchers had the numbers of bottles with their products contained within them.

Patients who met the eligibility criteria were randomized to compose one of the two research groups: experimental group (Calendula) and control group (EFA). Randomization was as follows: when participants entered the study they received their number, which occurred in ascending order; the distribution sequence of numbered bottles containing the product was previously generated by Microsoft Excel software, ensuring a random sample between the experimental and control groups. The number of bottles produced by compounding pharmacy was identical to the total number of research participants.

Participants applied EFA (control) or Calendula (experimental) topically in the prevention and treatment of radiodermatitis, as described in the research protocol: mode of application - application to the skin with a gauze soaked 
with the product of research in all treatment field every 12 hours (twice/day), from the first to the last day of radiotherapy session; first application - hospital: conducted by the research collaborator - average of $10 \mathrm{ml} /$ application; during application, study participant and/or family member/caregiver were advised on how to proceed with the use of the product in the household; subsequent applications hospital: applications were made daily by the research team or staff nurse, always after each session of radiotherapy; household: were carried out by the study participant and/ or family member/caregiver 12 hours after application in the hospital.

The primary outcome was the development of radiodermatitis, assessed by the toxicity grade, according to the criteria of the Radiation Therapy Oncology Group (RTOG): Grade 0 - no reaction, intact skin; Grade 1 - mild erythema, epilation and/or dry desquamation; Grade 2 - painful erythema, local moist desquamation and/or moderate edema; Grade 3 - confluent moist desquamation and/or severe edema; and Grade 4 - ulcerations, bleeding and/or necrosis ${ }^{(3)}$. The participant's skin in the irradiation field was evaluated in the first radiotherapy session, every five sessions and 30 days after the end of treatment. The evaluation of skin toxicity was performed by a team of trained researchers.

We conducted a pilot test in 30 days, which had 16 participants, allowing the sample calculation of 66 patients, 33 in each group, considering a minimum difference of $30 \%$ between groups, statistical power of $80 \%$ and significance level of $5 \%$.

The two groups (experimental and control) were compared according to the clinical, socioeconomic, demographic and outcome (univariate analysis). Chi-square, Fisher and $\mathrm{G}$ Williams tests in categorical variables were used. For quantitative variables we used U Mann-Whitney and Wilcoxon tests.

Survival analysis: Data were censored in the occurrence of one of the following facts: Using any other type of product into the skin at the treatment site at any time of the study, deficit in compliance with the intervention and following-up the study orientations, abandon the study or death. Survival time was calculated as the interval between the dates of treatment baseline to the date of grade 1 radiodermatitis development. Survival curves were estimated by Kaplan-Meier method without stratification. To compare the survival curves we used the Mantel-Haenzel test (logrank). For data analysis and survival charts we used Bioestat $^{\circledR}$ and R 2.5.0 softwares. For all tests, 5\% significance level was adopted.

\section{RESULTS}

We included 51 participants in the study, 27 of them were allocated to EFA group and 24 to the Calendula group, as shown in Figure 1. The number estimated by sample size calculation was not reached, but the data collection period was terminated due to research schedule.

Most participants were male, white, married, with elementary education, family income 1-2 minimum wages and covered by the Brazilian Unified Health System (SUS).
EFA group had an average age of $60.44 \pm 10.53$ and the $\mathrm{Ca}-$ lendula group an average age of $62.38 \pm 12.71$. With regard to the profession/occupation, we highlight in EFA group, there were seven (25.93\%) farmers and four (14.81\%) drivers; in Calendula group, there were six $(25 \%)$ farmers and five (20.83\%) salesmen/businessman. Most of the participants of EFA and Calendula groups presented history of smoking, alcohol use and sun exposure.

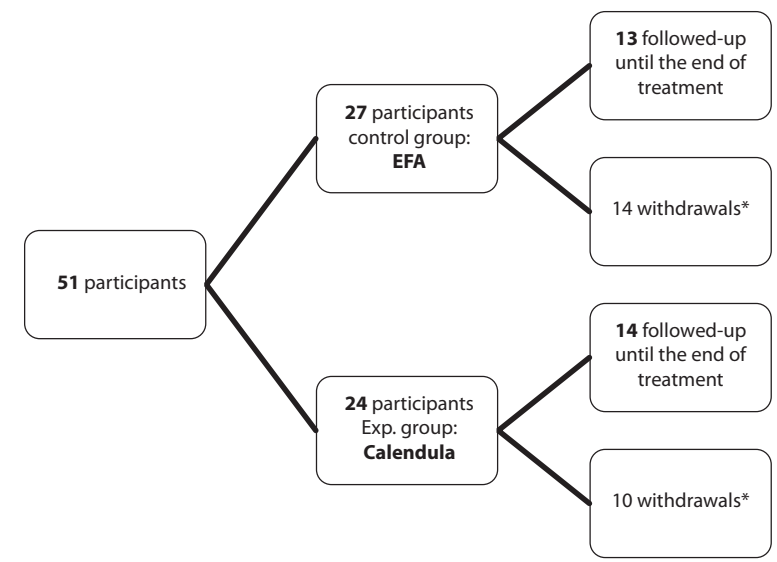

Figure 1 - Participants` flowchart of randomized controlled clinical trial. Curitiba/PR - 2011-2012.

*The causes of participants` withdrawals by the end of radiotherapy in EFA group were: nine due to the use of another product on the skin at the treatment field; two withdrawals were due to non-agreement with the the consent forms, two deaths and one deficit in compliance to the intervention; Calendula group: Five used other product on the skin at the treatment field, and three withdrawals were due to nonagreement with the consent forms and two deaths.

With regard to clinical diagnosis, there was a predominance of laryngeal cancer (33.33\%), followed by pharyngeal cancer (25.93\%), in the EFA Group; in the Calendula Group, larynx and pharynx cancers had the same incidence, presenting seven $(29.17 \%)$ cases each. In the radiotherapy treatment, there was a predominance of concomitant chemotherapy in EFA group (51.85\%) and Calendula group (54.17\%), as observed in treating with Cobalt-60 (power of $1.25 \mathrm{MeV}$ ) in both groups (EFA $=88.89 \%$ and Calendula 83.33\%). EFA group had an average of $36.11 \pm 1.78$ sessions and the Calendula group an average of $35.67 \pm 2.91$ sessions. The radiation doses on EFA group averaged 438.1 \pm 6977.04 centigray and in Calendula group an average of $6812.5 \pm 459.9$ centigray. Regarding diet, participants were fed orally in $92.59 \%$ in EFA group and $70.83 \%$ in Calendula group. Thus, we emphasize the similarities of the groups and their potential comparison.

We observe in Table 1 the data for the assessment of skin (toxicity grade) according to the criteria of the $\mathrm{RTOG}^{(3)}$, every 5 sessions, from baseline to end of treatment and 30 days later. From the $1^{\text {st }}$ to the $5^{\text {th }}$ session of radiotherapy none of the participants developed radiodermatitis in EFA and Calendula groups, as well as grade 4, i.e., the maximum grade of radiodermatitis was not observed in participants throughout treatment. No interruption of treatment occurred due to the development of radiodermatitis grade.

Radiodermatitis was developed from the $10^{\text {th }}$ session of radiotherapy, a small number of patients had grade 1 $(\mathrm{EFA}=11.11 \%$ and Calendula $=8.33 \%)$. At the $15^{\text {th }}$ session, most of the participants had no radiodermatitis (EFA 
$=59.26 \%$ and Calendula $=70.83 \%$ ), but in the EFA group $40.74 \%$ of participants had grade 1 . In the $20^{\text {th }}$ session, the participants $(\mathrm{EFA}=70.37 \%$ and Calendula $=66.67 \%)$ had grade 1 radiodermatitis and both groups showed a small number of radiodermatitis grade $2(\mathrm{EFA}=7.41 \%$ and $\mathrm{Ca}-$ lendula $=8.33 \%)$. At the $25^{\text {th }}$ session, remained the highest incidence of radiodermatitis grade 1 in EFA group (65.22\%) and Calendula (63.64\%), followed by grade 2 in EFA group (34.78\%) and grade 2 and grade 3 in Calendula group (13.64\% each).

Table 1 - Development of radiodermatitis in the participants of EFA and Calendula groups from baseline to end of treatment Curitiba, PR, 2011-2012.

\begin{tabular}{|c|c|c|c|c|}
\hline \multirow{3}{*}{$\begin{array}{l}\text { Radiodermatitis } \\
\text { Sessions of radiotherapy }\end{array}$} & \multirow{2}{*}{\multicolumn{2}{|c|}{$\begin{array}{l}\text { EFA Group } \\
(\mathrm{n}=27)\end{array}$}} & \multirow{2}{*}{\multicolumn{2}{|c|}{$\begin{array}{c}\text { Calendula } \\
\text { Group }(n=24)\end{array}$}} \\
\hline & & & & \\
\hline & $n$ & $\%$ & $\mathrm{n}$ & $\%$ \\
\hline $\begin{array}{l}\mathbf{1 0}^{\text {th }} \text { session } \\
\text { Grade } 0 \\
\text { Grade } 1 \\
\text { Total }\end{array}$ & $\begin{array}{c}24 \\
3 \\
27\end{array}$ & $\begin{array}{c}88.89 \\
11.11 \\
100\end{array}$ & $\begin{array}{c}22 \\
2 \\
24\end{array}$ & $\begin{array}{l}91.67 \\
8.33 \\
100\end{array}$ \\
\hline $\begin{array}{l}\mathbf{1 5}^{\text {th }} \text { session } \\
\text { Grade } 0 \\
\text { Grade } 1 \\
\text { Grade } 2 \\
\text { Total }\end{array}$ & $\begin{array}{c}16 \\
11 \\
0 \\
27\end{array}$ & $\begin{array}{c}59.26 \\
40.74 \\
0 \\
100\end{array}$ & $\begin{array}{c}17 \\
6 \\
1 \\
24\end{array}$ & $\begin{array}{c}70.83 \\
25 \\
4.17 \\
100\end{array}$ \\
\hline $\begin{array}{l}\mathbf{2 0}^{\text {th }} \text { session } \\
\text { Grade 0 } \\
\text { Grade } 1 \\
\text { Grade } 2 \\
\text { Total }\end{array}$ & $\begin{array}{c}6 \\
19 \\
2 \\
27\end{array}$ & $\begin{array}{c}22.22 \\
70.37 \\
7.41 \\
100\end{array}$ & $\begin{array}{c}6 \\
16 \\
2 \\
24\end{array}$ & $\begin{array}{c}25 \\
66.67 \\
8.33 \\
100\end{array}$ \\
\hline $\begin{array}{l}\mathbf{2 5}^{\text {th }} \text { session } \\
\text { Grade 0 } \\
\text { Grade } 1 \\
\text { Grade } 2 \\
\text { Grade } 3 \\
\text { Total }\end{array}$ & $\begin{array}{c}0 \\
15 \\
8 \\
0 \\
23\end{array}$ & $\begin{array}{c}0 \\
65.22 \\
34.78 \\
0 \\
100\end{array}$ & $\begin{array}{c}2 \\
14 \\
3 \\
3 \\
22\end{array}$ & $\begin{array}{c}9.09 \\
63.64 \\
13.64 \\
13.64 \\
100\end{array}$ \\
\hline $\begin{array}{l}\mathbf{3 0}^{\text {th }} \text { session } \\
\text { Grade } 0 \\
\text { Grade } 1 \\
\text { Grade } 2 \\
\text { Grade } 3 \\
\text { Total }\end{array}$ & $\begin{array}{c}0 \\
7 \\
6 \\
4 \\
17\end{array}$ & $\begin{array}{c}0 \\
41.18 \\
32.29 \\
23.53 \\
100\end{array}$ & $\begin{array}{c}2 \\
10 \\
3 \\
2 \\
17\end{array}$ & $\begin{array}{c}11.76 \\
58.82 \\
17.65 \\
11.76 \\
100\end{array}$ \\
\hline $\begin{array}{l}\mathbf{3 5}^{\text {th }} \text { session } \\
\text { Grade } 0 \\
\text { Grade } 1 \\
\text { Grade } 2 \\
\text { Grade } 3 \\
\text { Total }\end{array}$ & $\begin{array}{l}0 \\
4 \\
1 \\
2 \\
7\end{array}$ & $\begin{array}{c}0 \\
57.14 \\
14.29 \\
28.57 \\
100\end{array}$ & $\begin{array}{l}2 \\
5 \\
0 \\
2 \\
9\end{array}$ & $\begin{array}{c}22.22 \\
55.56 \\
0 \\
22.22 \\
100\end{array}$ \\
\hline $\begin{array}{l}\text { Last session } \\
\text { Grade } 0 \\
\text { Grade } 1 \\
\text { Grade } 2 \\
\text { Grade } 3 \\
\text { Total }\end{array}$ & $\begin{array}{c}1 \\
6 \\
3 \\
3 \\
13 \\
\end{array}$ & $\begin{array}{c}7.69 \\
46.15 \\
23.08 \\
23.08 \\
100\end{array}$ & $\begin{array}{c}3 \\
8 \\
1 \\
2 \\
14\end{array}$ & $\begin{array}{c}21.43 \\
57.14 \\
7.14 \\
14.29 \\
100 \\
\end{array}$ \\
\hline $\begin{array}{l}\mathbf{3 0} \text { days after the treatmer } \\
\text { Grade } 0 \\
\text { Grade } 1 \\
\text { Grade } 2 \\
\text { Total } \\
\text { No aderence }\end{array}$ & $\begin{array}{c}9 \\
0 \\
1 \\
10 \\
3\end{array}$ & $\begin{array}{c}90 \\
0 \\
10 \\
100 \\
23.08\end{array}$ & $\begin{array}{c}11 \\
1 \\
0 \\
12 \\
2\end{array}$ & $\begin{array}{c}91.67 \\
8.33 \\
0 \\
100 \\
14.29\end{array}$ \\
\hline
\end{tabular}

p-values were not statistically significant.

In the $30^{\text {th }}$ session, radiodermatitis grade in the participants ranged from 0 to 3 , the most frequent grade was 1 in both groups $(\mathrm{EFA}=41.18 \%$ and Calendula $=58.82 \%)$, however, the percentage of grade 2 and 3 in EFA was higher compared to the Calendula group. Radiodermatitis grade 1 was more frequent in the $35^{\text {th }}$ session and at the last treatment session $(\mathrm{EFA}=57.14 \%$ and Calendula $=55.56 \%)$. In the last session, EFA Group presented higher incidence of grades 2 and 3 (46.15\%) compared to Calendula group (21.43\%). In the assessment performed 30 days after the end of treatment, most of the participants had no radiodermatitis, and one (10\%) in the EFA group had grade 2 and one $(8.33 \%)$ in the Calendula group had grade 1 .

In Table 2 it is observed the period of greatest incidence of development of radiodermatitis, which occurred between $15^{\text {th }}-25^{\text {th }}$ sessions in both groups $(\mathrm{EFA}=88.89 \%$ and Calendula $=87.50 \%)$. EFA and Calendula groups showed peak incidence at the $20^{\text {th }}$ session of treatment, showing, respectively, 10 (37.04\%) and 11 (45.83\%) participants with radiodermatitis.

With regard to the maximum radiodermatitis grade development, we highlight that in EFA group grades 1 and 2 were similar, showing respectively $44.44 \%$ and $40.74 \%$. In Calendula group, most participants had grade 1 , with a significant percentage of $62.50 \%$ (Table 2).

Table 2 - Period of radiodermatitis development grade of toxicity in EFA and Calendula groups - Curitiba, PR, 2011-2012.

\begin{tabular}{lcc}
\hline \multirow{2}{*}{ Radiodermatitis } & $\begin{array}{c}\text { EFA group } \\
(\mathrm{n}=27)\end{array}$ & $\begin{array}{c}\text { Calendula group } \\
(\mathrm{n}=24)\end{array}$ \\
\cline { 2 - 3 } & $\mathrm{n}(\%)$ & $\mathrm{n}(\%)$
\end{tabular}

Period for the development of radiodermatitis

$\begin{array}{lcr}10 \text { sessions } & 3(11.11) & 2(8.33) \\ 15 \text { sessions } & 8(29.63) & 5(20.83) \\ 20 \text { sessions } & 10(37.04) & 11(45.83) \\ 25 \text { sessions } & 6(22.22) & 5(20.83) \\ 30 \text { sessions } & 0(0) & 1(4.17)\end{array}$

Highest development of radiodermatitis grade (RTOG)

\begin{tabular}{cccc}
1 & $12(44.44)$ & $15(62.50)$ & \\
2 & $11(40.74)$ & $3(12.50)$ & $\mathrm{p}=0.1592$ \\
3 & $4(14.81)$ & $6(25)$ & \\
\hline
\end{tabular}

p-values were not statistically significant - Williams G-test.

After specifically analysis of the radiodermatitis grades between groups, we observed that there was statistically significant evidence ( $p$-value $=0.0120$ ) as the proportion of radiodermatitis grade 2 in EFA group is higher than the proportion in the Calendula group.

We highlight the prevalence of concomitant radiotherapy treatment with chemotherapy in both study groups. Thus, to assess time to the development of radiodermatitis, only participants who underwent concurrent chemotherapy (enhancer of radiodermatitis) $^{(3-4)}$, the period of higher incidence was during the $15^{\text {th }}$ to the $20^{\text {th }}$ session, EFA group $(71.42 \%)$, and in the $20^{\text {th }}$ session in the Calendula group (53.85\%). When checking the radiodermatitis grade in the participants, we observed that grade 2 had become more frequent in EFA group (57.14\%) and grade 1 in Calendula group (61.54\%). The maximum radiodermatitis grade in participants who underwent concomitant chemotherapy with radiotherapy showed significant statistical difference between the EFA and Calendula groups ( $\mathrm{p}$-value $=0.0179$ ) 
Conducting Kaplan-Meier curve, we observed that the median survival time of the participants in EFA group is equal to 20 days, around the $20^{\text {th }}$ treatment session is the minimum time in which we expect $50 \%$ of treated participants present radiodermatitis grade 1 . Since the median survival time of the participants of Calendula group is equal to 25 days, or approximately at the $25^{\text {th }}$ session of treatment is the minimum time in which it is expected $50 \%$ of treated patients present radiodermatitis grade 1 (Figure 2).

We highlight that EFA group survival curve remains always below the Calendula group survival curve. Thus, the risk for radiodermatitis grade 1 is greater for the EFA group than Calendula group at every point of the trajectory ( $\mathrm{p}-$ value $=0.00402)($ Figure 2).

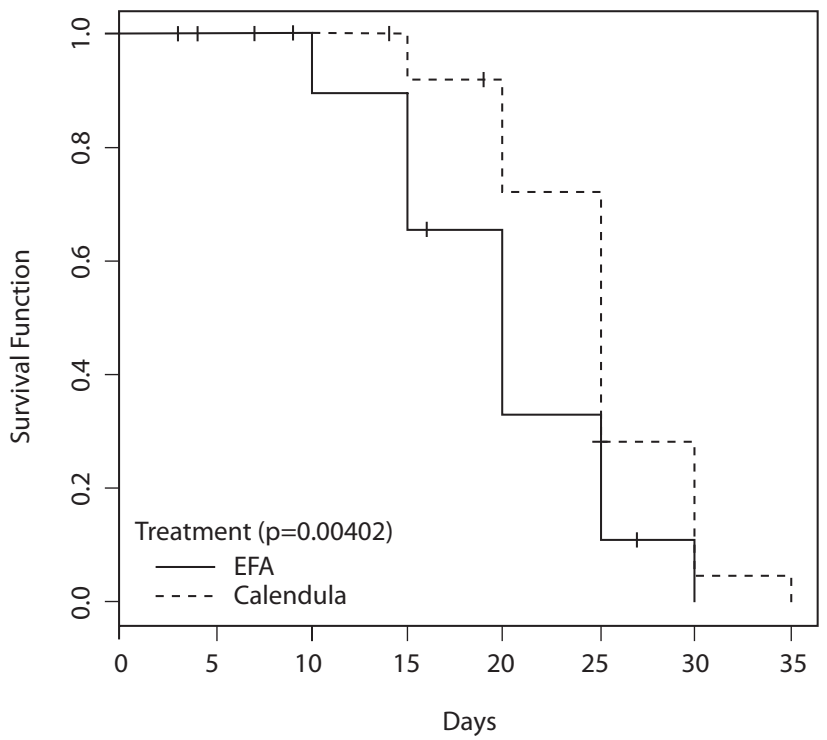

Show statistical significance ( $\mathrm{p}$-value= 0.00402) - Mantel-Haenzel Test (log-rank).

Figure 2 - Kaplan-Meier curve comparing the time to event of radiodermatitis of EFA and Calendula groups. Curitiba/PR - 20112012.

\section{DISCUSSION}

Studies show that radiodermatitis usually develop after the second week of treatment ${ }^{(3)}$. This fact was confirmed in this study, in which radiodermatitis was developed from the $10^{\text {th }}$ session of treatment in both groups as grade 1 . Thus, as radiotherapy goes on, increased skin toxicity is common as observed in the present study results.

At the $15^{\text {th }}$ session of treatment, the EFA group had 11 (40.74\%) participants with radiodermatitis grade 1 , while the Calendula group had almost twice as many participants with the same toxicity grade (25\%). Through this, Calendula group prevented more effectively the development of radiodermatitis compared to EFA group. In the $20^{\text {th }}$ session, most of the participants showed radiodermatitis grade 1 , as well as in the same period began the development of radiodermatitis grade 2 in both groups.

At the $25^{\text {th }}$ session EFA group presented all participants with grade $1(65.22 \%)$ or grade $2(34.78 \%)$ of radiodermatitis. Calendula group presented radiodermatitis grade 0 (9.09\%) grade $1(63.64 \%)$ grade $2(13.64 \%)$ and grade 3 (13.64\%), in other words, the latter group had a greater va- riety of skin toxicity. Thus, both groups had substantially the same radiodermatitis grade 1; grade 2 remained more incident in EFA group. We emphasize that there were participants in the Calendula group who still had no signs of radiodermatitis during the treatment period.

At the $30^{\text {th }}$ session, the radiodermatitis grade of the participants in both groups ranged from 0 to 3 . Comparing the two groups, we noted that only the Calendula group had participants without radiodermatitis (11.76\%); grade 1 were more prevalent in both groups $(\mathrm{EFA}=41.18 \%$ and Calendula $=58.82 \%)$, however, with a higher percentage in Calendula group; radiodermatitis grade 2 and grade 3 had exactly twice as many participants in EFA group when compared to Calendula group. Therefore, Calendula group best prevents the radiodermatitis development when compared to EFA group, Calendula group had lower skin toxicity grades.

At the $35^{\text {th }}$ session of treatment the Calendula group also had two (22.22\%) participants without radiodermatitis and two $(22.22 \%)$ participants grade 3 , with prevalence of grade $1(55.56 \%)$. On the other hand, the EFA group presented grade 1-3, being more frequent grade 1 (57.14\%).

In the last treatment session EFA group presented higher incidence in grade 2 and grade $3(46.15 \%)$ com- $^{-}$ pared to Calendula group (21.43\%). Calendula group had 3 participants with radiodermatitis grade $0(21.43 \%)$ and had the highest rate of radiodermatitis grade 1 (57.14\%). This reinforces previous findings that Calendula prevents the development of radiodermatitis and decreases the toxicity of the treatment.

In the assessment performed 30 days after the end of treatment, the majority of participants' (EFA $=90 \%$ and Calendula $=91.67 \%)$ radiodermatitis were not developed, a fact that corroborates to other author's information ${ }^{(2)}$, which showed that about six weeks after the treatment the skin reactions, except the most serious, were healed. In the EFA group 10\% had grade 2 and in the Calendula group 8.33\% had grade 1 in this period. This difference in toxicity grades between the groups may be related to the therapeutic response to the products.

In the overall analysis, the period of greatest frequency of radiodermatitis occurred from the $15^{\text {th }}$ to the $25^{\text {th }}$ radiotherapy session, in both groups, with the peak incidence at the $20^{\text {th }}$ session. EFA group began developing radiodermatitis prior to the Calendula group. In relation to the maximum radiodermatitis grade developed by the participants, we observed that EFA group had almost the same percentage of grade 1 (44.44\%) and grade $2(40.74 \%)$. On the other hand, the highest incidence in the Calendula group was grade 1 (62.50\%), however, this group also had the greatest number of participants with radiodermatitis grade $3(25 \%)$ when compared to the EFA group (14.81\%).

The development of radiodermatitis grade 1 and 3 showed no significant statistical difference between treatments with EFA and Calendula. However, there was statistically significant evidence $(p$-value $=0.0120)$ for the radiodermatitis grade 2, EFA group had a higher incidence of this grade than Calendula group, that is, Calendula was 
significantly more effective than EFA to prevent the development of radiodermatitis grade 2.

Regarding the concomitant radiotherapy and chemotherapy treatments, which was observed in over $50 \%$ of participants in both groups, some studies ${ }^{(3-4)}$ indicate that these patients are more likely to develop radiodermatitis, that is, this adverse effect is amplified. In the results of these participants, radiodermatitis in EFA Group had a higher incidence from the $15^{\text {th }}$ to the $20^{\text {th }}$ session $(71.42 \%)$ of treatment while most of the participants of Calendula group presented radiodermatitis on the $20^{\text {th }}$ session $(53.85 \%)$. Thus, EFA group developed radiodermatitis before Calendula group in concomitant treatment of participants.

Considering the isolated analysis of participants who underwent concomitant treatment, the maximum development of radiodermatitis grade presented was different between the two groups. Grade 2 was more frequent in the EFA group (57.14\%) and grade 1 was more frequent in the Calendula group (61.54\%). We highlight that the toxicity grade of the skin was statistically different between groups $(p=0.0179)$. Thus, most participants of Calendula group showed the lowest radiodermatitis grades, that is, Calendula was significantly more effective than EFA in relation to the maximum grade of skin toxicity.

In a blind randomized controlled clinical trial of 357 patients with head and neck, breast and anorectal cancer undergoing radiotherapy treatment, it was found that $\mathrm{pa}-$ tients who were concomitantly treated with chemotherapy had significantly worse skin reactions, both subjectively and objectively ${ }^{(10)}$. As in another randomized controlled clinical trial with 506 patients with head and neck cancer that showed a higher incidence of this reaction in patients concomitantly treated with chemotherapy, supporting the current research ${ }^{(11)}$.

From the results presented, Calendula is a protective factor for the development of radiodermatitis in patients on concomitant treatment with chemotherapy, despite these people being at greatest risk for its development, Calendula proved to be significantly more effective.

By means of Kaplan-Meier curve, we presented survival curve for EFA group, which was always below the Calendula group survival curve due to lower risk of developing radiodermatitis grade 1 , which makes the usage of Calendula more effective, with statistical significance $(\mathrm{p}=0.00402)$.

The effects of Calendula on the skin are remarkable and recognized throughout the world due to its healing activ$\mathrm{ity}^{(8)}$, which may explain the best therapeutic response in radiodermatitis on the current research. A blind randomized study with 254 women undergoing radiotherapy for breast cancer compared the usage of calendula (126 patients) with Trolamine ${ }^{\circledR}$ (128 patients) and found that the incidence of radiodermatitis grade 1 and 2, as well as local pain and discontinuation of treatment, were lower in patients who had used Calendula ${ }^{(1)}$. This result was presented in other studies $^{(12-16)}$, which indicated Calendula as a product with a significant protective effect on radiodermatitis.

Through the presented results, we observed that the Calendula group achieved better therapeutic responses in preventing and/or minimizing the development of radiodermatitis and toxicities grades in the skin of patients with head and neck cancer compared to the EFA group.

\section{CONCLUSION}

Radiodermatitis is one of the most common adverse effects of radiotherapy, however, it should be prevented, minimized and/or treated by nurses according to recommendations and/or interventions based on scientific evidence. The present study demonstrated the effectiveness of Calendula in the prevention and treatment of radiodermatitis in patients with head and neck cancer. The survival rate during radiodermatitis development of patients using the Calendula was higher compared to that of patients using EFA, but the sample size may have affected the statistical significance.

The limitations presented in the study refer to disadvantages in the performance of clinical trials, related to the cost, because they are expensive; require long time for their development and high number of qualified human resources. Also, it is worth noting as difficulties: keeping participants until the end of the study; constant assessments with the participants for a long period of data collection; control of confounder variables; and cooperation of other health professionals in the clinical trial, which interfere with the therapeutic approach researched.

The results of this research collaborate to the professional nursing practice, providing rationale for an evidencebased practice; however, the consolidation of more studies on the subject is required, as well as its performance with a larger number of participants, since scientific evidence seems to be incipient and still not enough to support oncology nursing and/or recommend the use of products for the prevention and/or treatment of radiodermatitis, there is a gap of knowledge regarding the subject. Furthermore, we emphasize the importance of clinical trials, which are fundamental to the achievement of a safe, effective and quality care for patients, which should be constantly stimulated by the institutions.

\section{RESUMO}

Objetivo: Avaliar a eficácia da Calendula officinalis em relação aos Ácidos Graxos Essenciais na prevenção e tratamento de radiodermatite. Método: Trata-se de ensaio clínico randomizado duplo cego realizado com 51 pacientes com câncer de cabeça e pescoço em tratamento radioterápico divididos em dois grupos: controle (27) e experimental (24). Resultados: Há evidência estatística significativa (p-valor $=0,0120)$ de que a proporção de radiodermatite grau 2 no Grupo Ácidos Graxos Essenciais é superior ao Grupo Calêndula. Por meio da curva de Kaplan-Meier observa-se que a sobrevida do Grupo Ácidos Graxos Essenciais manteve-se sempre abaixo da curva de sobrevida do Grupo Calêndula, devido ao menor risco de desenvolver radiodermatite grau 1, o que torna a utilização da Calêndula mais 
eficaz, com significância estatística (p-valor =0,00402). Conclusão: A Calêndula exibiu melhor resposta terapêutica do que o Ácidos Graxos Essenciais na prevenção e tratamento da radiodermatite.

Registro Brasileiro de Ensaios Clínicos: RBR-237v4b.

\section{DESCRITORES}

Calêndula; Radiodermatite; Pesquisa em Enfermagem Clínica; Enfermagem Oncológica; Ensaio Clínico.

\section{RESUMEN}

Objetivo: Evaluar la eficacia de la Calendula officinalis con respecto a los Ácidos Grasos Esenciales en la prevención y tratamiento de radiodermatitis. Método: Se trata de ensayo clínico randomizado doble ciego realizado con 51 pacientes con cáncer de cabeza y cuello en tratamiento radioterápico divididos en dos grupos: control (27) y experimental (24). Resultados: Existe evidencia estadística significativa ( $p$-valor $=0,0120$ ) de que la proporción de radiodermatitis grado 2 en el Grupo Ácidos Grasos Esenciales es superior al Grupo Caléndula. Por medio de la curva de Kaplan-Meier se observa que la supervivencia del Grupo Ácidos Grasos Esenciales se mantuvo siempre por debajo de la curva de supervivencia del Grupo Caléndula, en virtud del menor riesgo de desarrollar radiodermatitis grado 1, lo que hace la utilización de la Caléndula más efectiva, con significación estadística (p-valor = 0,00402). Conclusión: La Caléndula exhibió mejor respuesta terapéutica que los Ácidos Grasos Esenciales en la prevención y tratamiento de la radiodermatitis. Registro Brasileño de Ensayos Clínicos: RBR-237v4b.

\section{DESCRIPTORES}

Calendula; Radiodermatitis; Investigación en Enfermería Clínica; Enfermería Oncológica; Ensayo Clínico.

\section{REFERENCES}

1. Prommier P, Gomez F, Sunyach MP, D'Hombres A, Carrie C, Montbarbon X. Phase III randomized trial of Calendula officinalis compared with Trolamine for the prevention of acut dermatitis during irradiation for breast cancer. J Clin Oncol. 2004;22(8):1447-53.

2. Dealey C. Cuidados de feridas: um guia para as enfermeiras. $3^{\text {a }}$ ed. São Paulo: Atheneu; 2008.

3. Brasil. Ministério da Saúde; Instituto Nacional de Câncer. Ações de enfermagem para o controle do câncer: uma proposta de integração ensino-serviço. $3^{\text {a }}$ ed. Rio de Janeiro: INCA; 2008.

4. Muniz RM, Zago MMF. The oncologic radiotherapy experience for patients: a poison-drug. Rev Latino Am Enfermagem [Internet]. 2008 [cited 2014 Aug 10];16(6). Available from: http://www.scielo.br/pdf/rlae/v16n6/10.pdf

5. Matsubara MGS, Villela DL, Hashimoto SY, Reis HCS, Saconato RA, Denardi UA, et al. Feridas e estomas em oncologia: uma abordagem interdisciplinar. São Paulo: Lemar; 2012.

6. Denardi UA, Matsubara MGS, Bicudo FG, Okane ES, Martins CA, Moscatello E. Enfermagem em radioterapia. São Paulo: Lemar; 2008.

7. Sartori LR, Ferreira MS, Perazzo FF, Mandalho LL, Carvalho JCT. Atividade antiinflamatória do granulado de Calendula officinalis L e Matricaria recutita. Rev Bras Farmacogn. 2003;13 Supl.1:17-9.

8. Lima A. Plantas medicinais no tratamento de feridas. Rio de Janeiro: EPUB; 2009. p. 59-63.

9. Brasil. Ministério da Saúde; Agência Nacional de Vigilância Sanitária. Instrução Normativa n. 5, de 11 de dezembro de 2008 . Determina a publicação da Lista de Medicamentos Fitoterápicos de Registro Simplificado. Diário Oficial da União, Brasília, 12 dez. 2008.

10. Wells M, Macmillan M, Raab G, MacBride S, Bell N, MacKinnon K, et al. Does aqueous or sucralfate cream affect the severity of erythematous radiation skin reactions? A randomized controlled trial. Radiother Oncol. 2004;73(2):153-62.

11. Elliott EA, Wright JR, Swann S, Nguyen-Tân F, Takita C, Bucci MK, et al. Phase III trial of an emulsion containing trolamine for the prevention of radiation dermatitis in patients with advanced squamous cell carcinoma of the head and neck: results of radiation therapy oncology group trial 99-13. J Clin Oncol. 2006;24(13):2092-7.

12. Andrade M, Clapis MJ, Nascimento TG, Gozzo TO, Almeida AM. Prevention of skin reactions due to teletherapy in women with breast câncer: a comprehensive review. Rev Latino Am Enfermagem [Internet]. 2012 [cited 2014 Sep 26];20(3):604-11. Available from: http:// www.scielo.br/pdf/rlae/v20n3/a24v20n3.pdf

13. Schneider F, Pedrolo E, Lind J, Schwanke AA, Danski MTR. Prevenção e tratamento de radiodermite: uma revisão integrativa. Cogitare Enferm. 2013;18(3):579-86.

14. Chargari C, Fromantin I, Kirova YM. Intérêt des applications cutanées en cours de radiothérapie pour la prévention et le traitement des épithéliites radio-induites. Cancer Radiother. 2009;13(4):259-66.

15. McQuestion M. Evidence-based skin care management in radiation therapy. Semin Oncol Nurs. 2006;22(3):163-73.

16. Bolderston A, Lloyd NS, Wong RK, Holden L, Robb-Blenderman L. The prevention and management of acute skin reactions related to radiation therapy: a systematic review and practice guideline. Support Care Cancer. 2006;14(8):802-17. 